Research Article/Araştırma Makalesi

The Effect of Using Erroneous Example on the Achievement of Some Statistical Concepts of $7^{\text {th }}$ Grade Students

\author{
Ramazan GÜRBÜZ *1 (D) İshak YILDIRIM 2 (D) Muhammed Fatih DOĞAN1 (D) \\ ${ }^{1}$ Adiyaman University, Faculty of Education, Adryaman, Turkey, rgurbuz@outlook.com,mfatihdogan@adiyaman.edu.tr \\ 2 Şanlıurfa Süleymaniye Secondary School, Şanlıurfa, Turkey, ishak.yildirim@hotmail.com \\ *Corresponding Author: rgurbuz@outlook.com
}

\begin{tabular}{|c|c|}
\hline Article Info & Abstract \\
\hline & $\begin{array}{l}\text { This research aims to determine the effectiveness of the erroneous } \\
\text { solution method on learning the line graph, mean, median, and mode }\end{array}$ \\
\hline 29 July 2021 & at $7^{\text {th }}$ grade. This is a semi-experimental study model based on teaching \\
\hline Accepted: $\quad 9$ November 2021 & $\begin{array}{l}\text { the concepts of statistics with erroneous examples. The participants of } \\
\text { the study were randomly selected } 70 \text { students studying in the } 7^{\text {th }} \text { grade }\end{array}$ \\
\hline $\begin{array}{l}\text { Keywords: Statistics education, } \\
\text { mean, median and mode, erroneous } \\
\text { based activities }\end{array}$ & $\begin{array}{l}\text { in the 2018-2019 academic year. Eight activities that involve erroneous } \\
\text { examples were used during the data collection process and an } \\
\text { achievement test was conducted as pre-test and post-test before and } \\
\text { after classroom implementation. The obtained data were analyzed }\end{array}$ \\
\hline doi $10.18009 /$ jcer.976155 & $\begin{array}{l}\text { using the SPSS package program. In order to examine the effect of } \\
\text { activities, a t-test was performed. The results of the analysis revealed }\end{array}$ \\
\hline Publication Language: Turkish & $\begin{array}{l}\text { that the erroneous solution method had a positive effect on learning the } \\
\text { concepts of line graph, mean, median, and mode. }\end{array}$ \\
\hline CrossMark CC. & $\begin{array}{l}\text { To cite this article: Gürbüz, R., Yıldırım, İ. \& Doğan, M. F. (2021). } \\
\text { Hata temelli aktivitelerin } 7 \text {. sınıf öğrencilerinin bazı istatistik } \\
\text { kavramlarındaki başarısı üzerindeki etkisi. Journal of Computer and } \\
\text { Education Research, } 9(18), 997-1021 \text {. DOI: } 10.18009 / \text { jcer. } 976155\end{array}$ \\
\hline
\end{tabular}

\title{
Hata Temelli Aktivitelerin 7. Sınıf Öğrencilerinin Bazı İstatistik Kavramlarındaki Başarısı Üzerindeki Etkisi
}

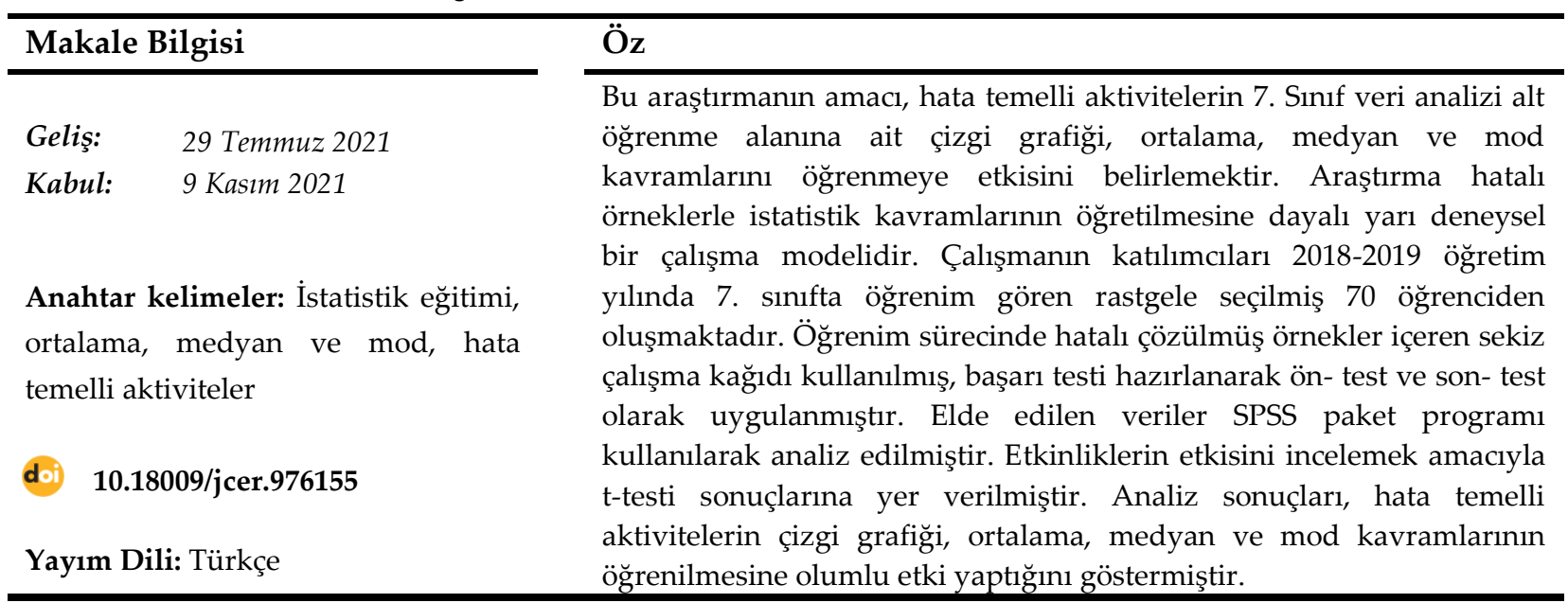




\title{
Summary
}

\section{The Effect of Erroneous Solution Method on the Achievement of Some Statistical Concepts of $7^{\text {th }}$ Grade Students}

\author{
Ramazan GÜRBÜZ *1(D) İshak YILDIRIM ${ }^{2}$ (D) Muhammed Fatih DOĞAN ${ }^{1}$ \\ ${ }^{1}$ Adryaman University, Faculty of Education, Adryaman, Turkey, rgurbuz@outlook.com, mfatihdogan@adiyaman.edu.tr \\ 2 Şanlıurfa Süleymaniye Secondary School, Şanlıurfa, Turkey, ishak.yildirim@hotmail.com \\ *Corresponding Author: rgurbuz@outlook.com
}

\section{Introduction}

The fundamental function of statistics is to provide the necessary information and helping an individual or an organization in the stage of analysis and interpretation of the information. Most jobs and organizations need statistics in the process of making a decision. The purpose of statistical science is to provide regular information, to recognize the present, and to make predictions about the future (Sevimli, 2010). Therefore, statistics is described as a discipline that produces and develops solutions depending on the changing business and living conditions. In order to learn and teach statistics, which has an enormous contribution to the regulation and improvement of human life and making healthy decisions about the future, should be established with fundamental solid steps from the ground (Gürbüz, 2007). The students struggle with learning the concepts of arithmetic mean, median, and mode, which are among the central tendency and diffusion measures (Memnun, 2008). In order to overcome these problems, it is necessary to use new teaching methods that aim to create opportunities for every student to learn mathematics.

Research on statistics teaching examined the effects of different methods to increase students' success such as; realistic mathematics education (Ersoy, 2013), learning through exams (Şan, 2014), cooperative learning (Özdemir, 2014), writing activities (Ünlü, 2015), and technology-assisted instruction (Yenilmez, 2016). Though these methods have positive effects on learning and teaching statistics, it is significant to put forward and try different methods to teach mathematics. The erroneous solution method is a method that puts students in a position to find errors. Unlike the understanding that expects students to learn from only correct solutions, the erroneous solution method is a method that makes students curious about finding the error and promotes them to find the truth from mistakes and learn the concepts. Thus, the method appears in a different way than the classical learning method. 
Our habits for the correct examples may cause us to think that erroneous solved examples are unnecessary, but learning from the erroneous solved examples is as important as the correct solved examples (Grobe \& Renkl, 2007). Generally, positive results were reported in the studies which examine the effect of erroneous solutions. Durkin (2012) investigated the effect of erroneous solutions on decimal notation and concluded that it was effective in learning. Türkdoğan and Baki (2021), analyzed how to give feedback depending on their experience when teachers found errors and concluded that the teacher gave 26 ways of feedback in this process, but they were not at a sufficient level regarding feedback techniques. Özkaya (2015) also examined the effect of error-based activities on increasing the level of teachers' knowledge. As a result of the study, Özkaya stated that the error-based activities help the teachers to develop effective content knowledge and understanding of the student, while the activities did not make a significant difference in terms of teaching knowledge. The erroneous solution method can be considered as a method that should be tried to understand the terms and concepts required to solve statistical problems, as it enables the person to compare and think errors. Students are obliged to infer on the basis of concepts to make mathematical operations on the statistical calculation. Thus, it is very important to learn the concepts first. Giving these concepts to students and asking them to internalize the concepts does not provide as effective learning as expected. With this point of view, the erroneous solution method put forth a different approach to the internalization of related concepts. It is interesting to teach concepts with examples of erroneous solutions and has a high chance of success.

This research aims to investigate the effect of the erroneous solution method which has been used in the teaching of different field courses in recent years. The study is conducted for this purpose is to examine the erroneous solution method on statistics for $7^{\text {th }}$ grade students.

\section{Method}

The research is designed as a semi-experimental study model including pre-test and post-test to determine the effectiveness of the erroneous solution method on learning the line graph, mean, median, and mode at $7^{\text {th }}$ grade. The participants of the study were 70 secondary school students in $7^{\text {th }}$ grade classes in Turkey. A Questioner was used for the pretest and post-test. In addition, the activities used in the study were designed to examine the 
effectiveness of the erroneous solution method on the concepts of the line graph, mode, median, and arithmetic mean. Eight activities that involve erroneous examples were used during the data collection process and an achievement test was conducted as pre-test and post-test before and after classroom implementation. To examine the effect of activities, a $t$ test was performed.

\section{Findings}

According to the independent sample t-test results, there was no significant difference $(p>0,05)$ in pre-test results. Thus, the pre-test showed that success levels of the experimental and control groups were close to each other. According to the dependent sample of $t$-test results, there is a statistically significant difference $(t=10,116$ and $p<0,001)$ between the pre-test result and the post-test result in the control group and between the pretest result and the post-test result $(t=16,782$ and $p<0,001)$ in the experimental group. As a result of the analysis, there was a significant difference $(t=0,403$ and $p<0,05)$ between the post-test results of the groups in favor of the experimental group. The differences between the post-tests can be interpreted that the process continued in the experimental group was more effective.

\section{Discussion and Results}

Considering the findings, both the control group and experimental group were similar before the implementation of the erroneous solution method. Results showed that the students in both the control group and the experimental group made progress. In addition, when the dependent sample t-test results are examined, the difference between the pre-test result and the post-test result of the experimental group is quite significant, and the erroneous solution activities made a significant contribution to the learning of the concepts of the line graph, mode, median, and arithmetic mean. This study shows that the erroneous solution method may have a positive effect on the success of $7^{\text {th }}$ grade students in learning some statistical concepts. 


\section{Giriş}

İnsanlar yaşamlarında birçok matematiksel işlem yapmaktadırlar. Alışverişte, harcamaları sınıflandırmada, bütçe planlamasında, harcama dağılımlarında farkında olarak ya da olmayarak matematik ve istatistik kullanmaktadırlar. İstatistik uzun yıllar öncesinde insanların kullanmış olduğu hesaplama yöntemlerindendir. Kararların veri desteğiyle şekillendiği günümüz dünyasında, istatistiğe ilişkin kavramlar hayatımızın her anında giderek artan bir şekilde kendini göstermektedir. Hayat akışı içerisinde toplumların ayakta kalabilmesi ve gelişebilmesi için istatistiksel verilerle başa çıkabilecek donanıma sahip olmaları gerekmektedir. Bu anlamda bireylerin verilerle kuşatılmış yaşamımızda kaliteli, üretken ve aktif bir yaşam sürdürebilmeleri birtakım becerilere sahip olmalarını gerektirmektedir. Bu bağlamda 2018 Milli Eğitim Bakanlığı tarafından yayınlanan Matematik Dersi Öğretim Programı (2018) incelendiğinde Veri İşleme öğrenme alanına, konunun önemine binaen ilkokul ve ortaokulun tüm sınıf düzeylerinde yer verildiği görülmektedir.

İstatistiğin temel fonksiyonu, karar alacak birey ya da örgütlere gerekli bilgileri sağlama, bu bilgileri çözümleme ve yorumlama aşamalarında yardımcı olmaktır. İnsanlar geleceğine dair planlarını, firmalar önümüzdeki yıllardaki satış ve büyüme stratejilerini, ülkeler de geleceğe dair ekonomi, sağlık, eğitim, ticaret vb. politikalarını bu verilere ait istatistiksel hesaplamalar üzerinden şekillendirmektedir. Örneğin, internette karşımıza çıkan reklamlar, ziyaret ettiğimiz sitelerin sıklığına göre işlenen veriler sayesinde karşımıza çıkmaktadır. Otomobil firmaları yıl içinde üretecekleri araba modellerine karar verirken, önceki yıllardaki satış rakamlarının analizlerini göz önünde bulundurmaktadırlar (Karaatlı, Helvacıoğlu, Ömürbek \& Tokgöz, 2012). Hayatın her alanında verilere bu kadar bağlı bir yaşam sürülmesi, bu tarz bilgilerin işlenmesi, analizi ve yorumlanması geleceğe yönelik isabetli tahminlerin yapılmasını çok önemli kılmaktadır. Kısacası bu tarz istatistiksel bilgiler hayatımızın her alanında karşımıza çıkmakta ve günümüz dünyasında bu bilgileri etkili bir şekilde işleyebilen, analiz edebilen ve yorumlayabilen kişi, kurum ve şirketler ön plana çıkmaktadır.

Matematik eğitimi alanında sıklıkla kullanılan Probleme Dayalı Öğrenme (PDÖ) modeli tıp alanındaki uygulamalardan da etkilenerek yeni bir strateji olarak karşımıza çıkmaya başlamıştır. Bu strateji, bilinen klasik uygulamaların aksine öğrencilere çözüm basamaklarında hatalar içeren örnekler verilmesine dayanmaktadır (Örnek \& Soylu, 2021). Hata yapma korkusuyla derse katılmayan, başarı duygusunu tadabilecekken risk almak 
istemeyen öğrenciler için hata temelli aktiviteler, hataların verimli hale gelmesini sağlayabilecek yapısalcı yaklaşıma uygun bir yöntem olacaktır (Akkuşçi, 2019).

Hata temelli aktivite (HTA), hataların bulunması ve doğruya ulaşılması konusunda öğrenciyi aktif kılan, sınıf içinde hatalardan öğrenmeyi mümkün kılan bir yöntemdir (Heinze \& Reiss, 2007). HTA doğru çözümlerden öğrencilerin öğrenmesini bekleyen anlayıştan farklı olarak öğrenciyi hatayı bulma konusunda meraklandıran, hatalardan doğruyu bulmaya ve öğrenmeye teşvik eden bir metottur. İnsanlar hayatta her daim olumlu durumlar istediği için negatif olarak görülen hatalardan uzak durmak ve hatasız olmak isterler (Konyalığlu, Özkaya \& Gedik, 2019). Öğretmenlerde çoğunlukla hataları görmezden gelirler (Türkdoğan \& Baki, 2021). Oysaki hatalardan öğrenmekte bir yöntem olabilir ve matematik öğrenimine katkı sağlayabilir (Heinze, 2005). Hataların sadece süreç planlamada değil süreç içinde de kullanılması fayda sağlayacaktır (Borasi, 1988).

Hata temelli aktiviteler kavramların içselleştirilmesinde farklı bir yaklaşım ortaya koymaktadır. Öğretilmek istenen kavramların öğrenciye aktarılmasından sonra hatalı çözüm içeren örneklerle sunulması ve öğrencinin hatayı bulması ve düzeltmesi yoluyla öğretilmesinin hem süreci ilgi çekici kılacağı hem de başarı şansını arttıracağı düşünülmektedir. Bu bağlamda, istatistiğin giderek gerçek hayatın merkezine yerleşmesi ve bu konunun anlaşılmasındaki zorluklar bu konunun öğretiminde HTA'nın öğrenme ortamına taşınmasını öğretimde sağlayabileceği katkılar açısından önemli kılmaktadır.

\section{İstatistik Konusunun Literatür İncelemesi}

İstatistiğin yaşamımızdaki öneminden hareketle istatistik öğretiminin nitelik ve niceliğinin iyileştirilmesi gerektiğine yönelik vurgular son yıllarda giderek artmaktadır (BenZvi, Gravemeijer \& Ainley, 2017). Farklı seviyelerde öğrenim gören öğrencilerin matematik önbilgilerinin ve soyut düşünme becerilerinin yetersizliğine bağlı olarak temel istatistik konularını öğrenme ve anlamlandırma da zorlandıkları belirtilmiştir (Ben-Zvi, ve diğg., 2017). Geleneksel öğretim yöntemine bağlı olarak öğrencilerin istatistiğe olumsuz bir tutumla yaklaştıkları da bilinmektedir (Garfield \& Gal, 1999). Enisoğlu (2014) yaptığı çalışma ile 7. sınıf öğrencilerinin veri analizi konusunda Aritmetik Ortalama, Medyan (Ortanca) ve Mod (Tepe Değer) kavramlarında çeşitli hatalar yaptıklarını belirlemiştir.

İstatistik öğretimine ilişkin çalışmaların çoğunda başarıyı arttırmaya yönelik farklı yöntemlerin etkileri incelenmiştir. Ersoy (2013), gerçekçi matematik eğitiminin; Şan (2014), sinav yoluyla öğrenmenin; Özdemir (2014), işbirlikli öğrenmenin; Ünlü (2015), yazma 
etkinliklerinin; Yenilmez (2016), teknoloji destekli öğretimin istatistik öğrenme alanında akademik başarıya etkilerini araştırmışlardır. Koparan, Güven ve Karataş (2014), proje tabanlı öğrenme yaklaşımının istatistiksel okuryazarlık seviyelerine etkisi ve istatistiğe yönelik tutumlara etkisini incelerken, Özmen (2015), yedi farklı fakültenin dokuz programında okuyan öğrencilerin istatistik okuryazarlığını incelemiştir. Hall ve Vance (2010), öz yeterlilik inancının istatistik eğitiminde motivasyon ve akademik başarının sürdürülebilmesine etkisini araştırmıştır. Franklin vd. (2007) ve Gaise Çalışma Grubu (2016), istatistik eğitiminde öğrenme kalitesini arttırmaya yönelik raporlar yayınlamışlardır. Üzerinde çalışılmış yöntemlerin, istatistik ve istatistik kavramlarının öğrenilmesi ve öğretilmesi konusunda olumlu etkileri olsa da çözüm üreten farklı yöntemlerin ortaya konulması istatistik öğretimine katkı sağlayacaktır.

\section{Hata Temelli Aktivite}

Hata Temelli Aktivite, kısaca kavram bilgisine sahip öğrencilere hatalı çözülmüş örneklerin verilerek, yapılan hataları bulup doğru çözümü elde etmelerinin istendiği bir yöntemdir. Heinze ve Reiss'e (2007) göre hata temelli aktivitelerin, hataların öğrenmeyi sağlaması amacıyla sınıf içinde kullanılmasına dayanan bir süreçtir. HTA, olumsuz olarak düşünülen hataların bir fırsata dönüşmesini sağlayabilir (Özkaya, 2015; Balak, 2021). RittleJohnson vd. (2010) ve Durkin (2012) tarafından yapılan çalışmalar doğru çözülmüş örneklerden öğrenme kadar hatalı çözülmüş örneklerden öğrenmenin de önemli olduğunu göstermiştir. VanLehn (1999), hataların daha derin öğrenmelere fırsatlar sunduğunu belirtmektedir.

Öğrencilere kavram yanılgısı içeren örnekleri sunmanın öğrencilerin hatalarını düzeltmek, kavramları doğru anlama ve işlem tecrübesi kazandırmak için yararlı olabileceği ifade edilmektedir (Durkin, Star \& Rittle- Johnson, 2017). Örneğin, yanlış örneklerin çalışılması ve vaka bazlı çalışılan örneklerde hataların belirlenmesi, tıp öğrencilerinin teşhis kavramları hakkındaki bilgilerini geliştirmeye yardımcı olmuştur (Stark, Kopp \& Fischer, 2011). Benzer şekilde, kısa süreli bir özel ders oturumunda hem doğru hem de yanlış çözümleri açılayan öğrencilerin, yalnızca doğru çözümleri açıklayan öğrencilere kıyasla çeşitli soru türlerine uygulanabilir doğru prosedürleri öğrenmeleri ve kullanmaları daha muhtemeldir (Siegler, 2002). Öğrencilerin sıklıkla yaptıkları hatalara odaklanmasını sağlamak, doğrular üzerine derinleşmelerine ve yanlışlardan uzaklaşmalarına olumlu yönde 
etki etmektedir (Durkin \& Rittle-Johnson, 2012; Van den Broek \& Kendeou, 2008; VanLehn, 1999). Siegler (2002), yaptığı çalışmada öğrencilerden sadece doğru çözümleri açıklamaları yerine hem doğru hem de yanlış çözümleri açıklamalarının istenmesinin öğrencilerde öğrenme konusunda daha fazla esnekliğe yol açtığını ve öğrencilerin doğruya ulaşmakta daha rahat hareket ettiğini belirtmiştir. Başka bir ifadeyle öğrencinin doğru çözümlerin yanı sıra yanlış çözümlerle de ilgilenmesi hatalı olanı daha kolay bulmasını ve hataların kaynağının keşfini kolaylaştırdığı sonucuna ulaşılmıştır. Bu yaklaşımla yapılan yanlışların nedenleri öğrenilmiş ve içselleştirilmiş olacağından, yeni problemlere daha farklı açılardan bakan öğrencilerin doğru ve hatalı olanı daha kolay bulabileceği savunulmaktadır (Siegler, 2002).

Hatalı çözümlerin etkisinin incelendiği çalışmalarda genel olarak olumlu sonuçlara ulaşıldığı görülmektedir. Durkin (2012) tarafından yapılan çalışmalarda ondalık gösterim konusunda hatalı çözümün etkisi araştırılmış ve öğrenmede etkili olduğu sonucuna ulaşılmıştır. Türkdoğan ve Baki (2021), öğretmenlerle yapmış oldukları çalışmada hata ile karşılaşınca tecrübelerine istinaden nasıl dönütler verdiklerini incelemişlerdir. Öğretmenlerin süreçte farklı şekilde dönüt verdiği fakat dönüt teknikleri konusunda yeterli düzeyde olmadıkları sonucuna ulaşılmıştır. Gedik (2014), hata temelli aktivitelerin öğretmenlerin alan bilgisine yönelik etkisini incelemeye yönelik yaptığı çalışmada hata temelli aktivitelerin öğretmenlerin alan bilgisine yönelik, bilişsel ve duyuşsal açıdan, katkı sağladığı sonucuna ulaşmıştır. Ayrıca Gedik (2014), Hata temelli aktivitelerin motivasyonel etkilerinin gözlendiği ve araştırmaya sevk ederek eleştirel düşünme becerilerini de geliştirdiğini belirtmiştir. Özkaya (2015), hata temelli aktivitelerin öğretmenlerin öğretimsel bilgi düzeylerini arttırmaya etkisini incelemiştir. Çalışma sonucunda hata temelli aktivitelerin öğretmenlerin alan bilgisi ve öğrenciyi anlama konularında gelişmesini sağlarken öğretim bilgisi açısından anlamlı bir farklılık oluşturmadığı sonucuna ulaşmıştır. Lynch ve Star (2014)'ın cebir üzerine yaptıkları çalışmada hatalı çözümlerle birlikte doğru çözümler karşılaştırmalı olarak kullanılmış ve öğrencileri katılıma teşvik etme, öğrencilerin düşüncelerini vurgulama konusunda HTA'nın daha faydalı olduğu sonucuna ulaşılmıştır. Hatalı çözümlerin içinde bulunduğu çoklu çözüm yöntemini çalışmalarında kullanan RittleJohnson, Star ve Durkin (2010); öğrencilerin daha ileri düzey bilgiye ulaşabildiğini ve bilgilerin daha kalıcı olduğunu belirtmişlerdir. Dokuzuncu sınıfta okuyan öğrenciler üzerinde çalışma yapan Akkuşci (2019), çalışmasında hata temelli aktivitelerin sınıf içi 
kullanımında öğrenci gelişimine etkisini incelemiş, hata temelli aktivitelerin öğrencilere bilişsel ve duyuşsal olarak olumlu etkileri olduğu sonucuna ulaşmıştır.

HTA'nın istatistik öğrenme alanındaki bazı kavramlara ilişkin öğrenci öğrenmesi üzerine etkisini ortaya koymak amacıyla bu araştırmada, HTA'nın 7. sınıf öğretim programında yer alan çizgi grafiği, mod, medyan ve aritmetik ortalama kavramlarının öğretimine etkisini incelemek amaçlanmıştır.

\section{Yöntem}

Araştırma, hatalı çözülmüş örneklerle istatistik kavramlarının öğretilmesi temelli ön test-son test kontrol grubu içeren deneysel çalışma modelidir. Bu çalışmada HTA'nın etkisini karşılaştırmak için deney ve kontrol gruplarının süreç sonundaki performansları karşılaştırılmıştır.

\section{Çalışma Grubu}

Bu araştırma 2018-2019 öğretim yılında, Türkiye'de bir ildeki ortaokulda öğrenim gören 15 tane 7. sınıf içinden kura ile seçilen iki sınıfta öğrenim gören toplam 70 yedinci sınıf öğrencisinin katılımıyla gerçekleştirilmiştir. Öğrencilerin hangi şubeden olduğuna bakılmaksızın tek sıra numaralı öğrencilerin kontrol grubu, çift sıra numaralı öğrencilerin ise deney grubu olmasına karar verilerek farklı sınıflara alınmışlardır.

\section{Veri Toplama Araçları}

Verilerin toplanmasında ön test ve son test için dokuz sorudan oluşan başarı testi kullanılmıştır. Bu testteki soruların seçiminde 7. Sınıf seviyesindeki kazanımlar göz önünde bulundurulmuştur. Aritmetik ortalama ile ilgili olan birinci, ikinci ve üçüncü sorular; mod ile ilgili olan dördüncü soru, medyan ile ilgili olan beşinci ve altıncı sorular ile aritmetik ortalama, mod, medyan içeren 7. soru "İstatistiğin Temel Kavramlarının Probleme Dayalı Öğrenme Yaklaşımıyla Öğretimi” (Sezer, 2013) isimli yüksek lisans tezinden alınmıştır. Çizgi grafiği ile ilgili olan sekizinci ve dokuzuncu sorular ise 7. sınıf ders kitabından alınmıştır (Erenkuş \& Savaşkan, 2018). Bu soruların seçilme sebebi hem kapsam geçerliliğinin sağlanması hem de daha önce kullanılmış ve uygulamaya uygun sorular olmasıdır (yordama geçerliliği). Bu soruların seçilme sürecinde iki matematik eğitimcisinin ve deneyimli iki matematik öğretmeninin görüşlerine başvurulmuştur. Uygulamadan önce 7. sınıfta okuyan iki öğrenci ile pilot uygulama gerçekleştirilmiştir. Öğrencilerin süreç içindeki rolleri, sunulan 
ifadelerin anlaşılabilirlikleri, verilen sürenin yeterliliği, verilen yanıtlar ve öğrencilerin görüşleri göz önünde bulundurularak sorular daha anlaşılabilir hale getirilmiş, verilen sürenin biraz daha uzatılmasına karar verilerek uygulamaya hazır hale getirilmiştir. Başarı testi Ek'1 de sunulmuştur.

\section{Çalışmada Kullanılan Çalışma Kă̆ı̆tları}

Deney grubunda HTA'nın etkisini belirlemek amacıyla sekiz hatalı çözüm etkinliği kullanılmıştır. Bu çalışma kağıtları ders kitabında bulunan örnek sorulardan seçilerek, küçük müdahalelerle uygulamaya hazır hale getirilmiştir. Bu çalışma kağıtlarının ilgili oldukları kazanımlar Tablo 1'de verilmiştir. Örnek olması açısından çalışma kağıtlarından biri Ek 2'de sunulmuştur.

Tablo 1. Çalışma kağıtlarının öğretim programı kazanımları ile ilişkisi

\begin{tabular}{|c|c|c|c|c|c|c|c|c|}
\hline $\mathrm{C}_{\text {Kazanımlar }}$ Etkinlikler & $\begin{array}{l}\text { Etk. } \\
\text { I }\end{array}$ & $\begin{array}{l}\text { Etk. } \\
\text { II }\end{array}$ & $\begin{array}{l}\text { Etk. } \\
\text { III }\end{array}$ & $\begin{array}{l}\text { Etk. } \\
\text { IV }\end{array}$ & $\begin{array}{l}\text { Etk. } \\
\text { V }\end{array}$ & $\begin{array}{l}\text { Etk. } \\
\text { VI }\end{array}$ & $\begin{array}{l}\text { Etk. } \\
\text { VII }\end{array}$ & $\begin{array}{l}\text { Etk. } \\
\text { VIII }\end{array}$ \\
\hline $\begin{array}{l}\text { Verilere ilişkin çizgi grafiği } \\
\text { oluşturur ve yorumlar. }\end{array}$ & $X$ & $X$ & & & & $X$ & & $X$ \\
\hline $\begin{array}{l}\text { Bir veri grubuna ait ortalama, } \\
\text { medyan ve modu bulur ve } \\
\text { yorumlar. }\end{array}$ & & & $X$ & $X$ & $X$ & $x$ & $x$ & $x$ \\
\hline
\end{tabular}

Enisoğlu'nun (2014) çalışmasında 7. sınıfta okuyan öğrenciler tarafından en sık yapıldığı belirtilen hatalar dikkate alınarak çalışma kağıtları hazırlanmıştır. Örnek olarak; medyan kavramı ile ilgili Enisoğlu'nun belirttiği “sıralanmamış veriler üzerinden yanlış karar verme" hatası beşinci çalışma kağıdında kullanılmıştır. Beşinci çalışma kağıdındaki örnek Resim 1'de, örnekte yapılmış mevcut hata basamağı Resim 2'de ve doğru çözümü Resim 3'te verilmiştir.

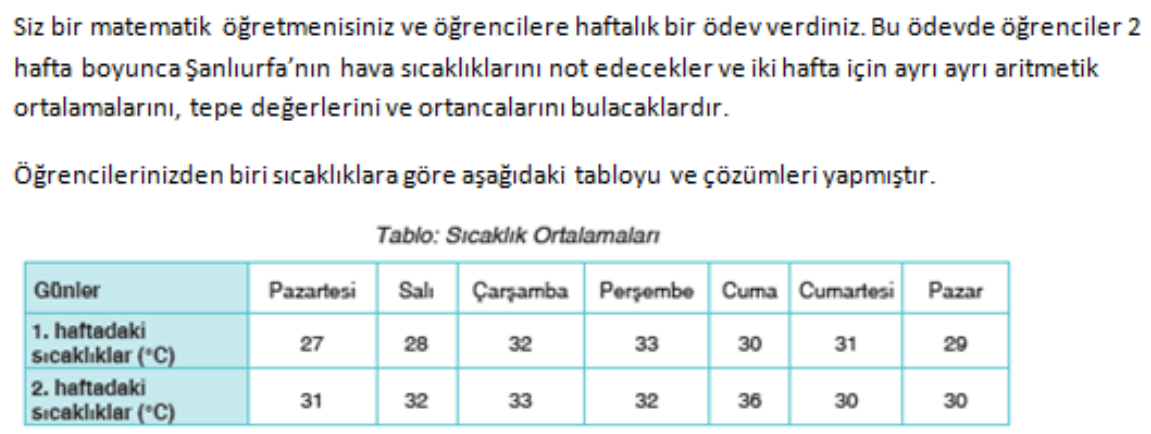

Resim 1. Beşinci çalışma kağıdında kullanılan örnek 


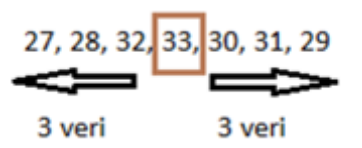

Medyan : 33

Resim 2:.Beşinci çalışma kağıdında medyana ilişkin hatalı çözüm

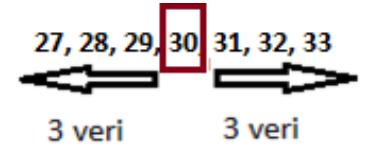

Medyan : 30

Resim 3. Beşinci çalışma kağıdında medyana ilişkin doğru çözüm

\section{Veri Toplama Süreci}

Araştırma kapsamında uygulamalara başlamadan bir hafta önce hazırlanan ölçme aracı bütün öğrencilere ön test olarak uygulanmıştır. Öğrencilerin gruplara ayrılma sebebi ve yapılacak araştırmayla ilgili kısa bir bilgilendirme yapıldıktan sonra deney grubunun dersleri araştırmacılardan biri tarafından, kontrol grubunun dersleri ise kurum beklentisi ve uyarısı dikkate alınarak öğretim programının aksatılmaması için tecrübe yılı uygulamayı gerçekleştiren araştırmacıyla aynı olan ve öğretmen yeterliliği bağlamında da benzer özellikler taşıdığı düşünülen başka bir matematik öğretmeni tarafından gerçekleştirilmiştir.

Deney grubunda bulunan araştırmacı "verilere ilişkin çizgi grafiği oluşturur ve yorumlar" ve "bir veri grubuna ait ortalama, ortanca ve tepe değeri bulur ve yorumlar" kazanımlarını iki ders saatinde anlatmış, öğrencilerin konuyu kavramasını sağlamaya çalışmıştır. Üçüncü ders saatine başlarken öğrenciler çalışma kağıtlarıyla ilgili bilgilendirilmiş, yönergeler sözlü olarak verilmiştir. Öğrenciler birinci etkinliği bitirdikten sonra varsa süreç ile ilgili yanlış anlamaları düzeltmek ve sürecin geri kalanının doğru şekilde tamamlanmasını sağlamak amacıyla nasıl bir yol izleneceği, hata olup olmadığı, bunları nasıl ifade ettikleri üzerine konuşulmuştur. Kavramların öğretimine dayanan iki ders saatinden sonra beş ders saati süresince hatalı çözüm içeren sekiz çalışma kağıdı uygulanmış ve her bir çalışma kağıdı uygulandıktan sonra toplanmıştır. Bu süreçte 1. ve 2. çalışma kağıdı "Verilere ilişkin çizgi grafiği oluşturur ve yorumlar" kazanımının öğretimi için, 3., 4., 5. ve 7. Çalışma kağıtları "Bir veri grubuna ait ortalama, ortanca ve tepe değeri bulur ve yorumlar" kazanımının öğretimi amacıyla ve 6. ve 8. çalışma kağıtları ise her iki kazanımın öğretimi amacıyla uygulanmıştır. Ders anlatımı ve çalışma kağıtlarının uygulanması iki haftalık süre içinde farklı ders saatleri kullanılarak yapılmıştır. Uygulama süreci boyunca öğrencilerin yer aldıkları çalışma kağıtları hakkında tartışma yapmaları sağlanarak, genel sınıf iletişiminin 
arttığı gözlemlenmiştir. Öğrenciler bu süreçte "pasif dinleyici” ve “öğretmenin aktardığ1 bilgiyi değişikliğe uğratmadan alan" rolleri yerine "derse aktif katılan”, "bilgiyi inşa eden" ve "inşa ettiği bilgiyi nasıl inşa ettiğini açılayan" rollerini üstlenmeleri yönünde teşvik edilmişlerdir.

Kontrol grubunda ise dersler Matematik Dersi Öğretim Programı (2018) dikkate alınarak yürütülmüştür. Bu süreçte konu ders kitabındaki düzene bağlı olarak öğretmen tarafından sözlü olarak anlatılmış ve öğretmen anlattıklarına ilişkin gerekli açıklamaları zaman zaman tahtaya yazmıştır. Bu süreçte öğrenciler sessiz ve hareketsiz bir şekilde yerlerinde oturarak öğretmeni dinlemişlerdir. Öğretmen tahtayı doldurduktan sonra öğrencilere tahtadaki açıklamaları defterlerine yazmaları için süre vermiştir. Bu süreçte öğretmen öğrencilere konuyla ilgili varsa soruları sormalarını istemiştir. Bu sırada öğretmen sınıfta dolaşarak öğrencilerin sorularına cevap vermiştir. Ancak tüm süreç boyunca belirli öğrenciler, öğretmenden izin alarak konuya ilişkin sorular sorabilmişlerdir. Ayrıca bu sürecin belli bir bölümünden sonra öğretmen konuyu anlatırken çizimlerle zaman kaybetmemek için kendisi tarafından önceden hazırlanmış olan konu özeti ve kitaptan örnekler içeren bir belgeyi akıllı tahtada açarak kullanmıştır. Anlattığı her kavramdan sonra alıştırmalar yapan öğretmen kavramlar bittikten sonra karışık örnekler çözmüştür. Örnekleri bitiren öğretmenin öğrencilere sorular sorarak konuyu pekiştirmeye çalıştı̆̆ görülmüştür.

Deney ve kontrol grubunda bu uygulamalar birbirine yakın zaman aralıklarında gerçekleştirilerek, iki grupta da uygulamalar bittikten sonra ölçme aracı son test olarak uygulanmıştır.

\section{Verilerin Analizi}

$\mathrm{Bu}$ araştırmada ön test ve son test ile toplanan nicel verilere ait parametrik testlerin yapılabilmesi için dağılımın normal dağılıma sahip olması gerektiğinden normallik testleri yapılmıştır.

Tablo 2. Ön test ve son testlere ait normallik değerleri

\begin{tabular}{|c|c|c|c|c|c|}
\hline Grup & Test & $\begin{array}{l}\text { Çarpıklık } \\
\text { Değeri }\end{array}$ & $\begin{array}{l}\text { Çarpıklığın } \\
\text { Standart } \\
\text { Hatası }\end{array}$ & $\begin{array}{l}\text { Basıklık } \\
\text { Değeri }\end{array}$ & $\begin{array}{l}\text { Basıklığın } \\
\text { Standart } \\
\text { Hatası }\end{array}$ \\
\hline Deney & Ön Test & 117 & ,398 &,- 149 & 778 \\
\hline Kontrol & &,- 082 & ,398 &,- 757 & ,778 \\
\hline Deney & Son Test &,- 363 & ,398 &,- 868 & ,778 \\
\hline Kontrol & & 077, & ,398 & $-1,222$ & ,778 \\
\hline
\end{tabular}


Bir dağılımın normalliğini sınamak için çarpıklık ve basıklık değerlerine bakılabilir, bu değerlerin -2 ile +2 arasında olması beklenmektedir (George \& Mallery; 2010). Tablo 2'ye göre elde edilen verilerin normal dağılım gösterdiği görülmüştür.

Ön test ve son test yardımıyla öğrencilerden alınan yanıtlar incelenirken aşağıdaki düzeyler ve bu düzeylere göre verilen puanlar göz önünde bulundurulmuştur. Ön test ve son test değerlendirmelerinde objektif olması açısından bir başka matematik öğretmeninin de değerlendirme yapması sağlanmıştır. Bu puanlamalar neticesinde elde edilen veriler SPSS paket programı kullanılarak analiz edilmiştir. Verilerin analizinde t-testi kullanılmıştır.

Başarı testi (Ek 1), Gürbüz ve Birgin (2012) tarafından geliştirilen ve kullanılan aşağıdaki ölçütler dikkate alınarak puanlandırılmıştır.

Tam Doğru (A): Matematiksel olarak sorunun eksiksiz yanıtı, her ölçücü tarafından tam doğru kabul edilecek yanitlar yer almaktadır. Kısmen Doğru (B): Büyük oranda doğrular içeren fakat tam doğruya göre eksik olan yanıtlar yer almaktadır. Doğrular Iç̧eren (C): Sonucun yanlış olmasına rağmen doğru çözümler de içeren yanıtlar yer almaktadır. Yanlış-1 (D): Kısmen doğru kabul edilebilecek ifadeler içermesine rağmen bu doğruların soru ile ilişkisinin net olarak kurulamadığı yanıtları içermektedir. Yanlış-2 (E): Yanlış yöntemler denenen fakat soruyu çözmek için çaba sarf edilen yanıtları içermektedir. Yanıtsız (F): Hiç yanıt vermemiş öğrencilerin yanıtları ile boş kalmasın diye yazılmış yanlış ifadeli yanıtları içermektedir.

Öğrencilerin tüm soruları A düzeyde yanıtlaması durumunda, okul sınavlarından da alıştı̆̆ı üzere 100 puan alması planlanmıştır. Buna bağlı olarak ilk 7 soru değerlendirilirken A düzeyinde bulunan her yanıt için 10, B düzeyinde bulunan her yanıt için 8, C düzeyinde bulunan her yanıt için 6, D düzeyinde bulunan her yanıt için 4, E düzeyinde bulunan her yanıt için 2 ve $\mathrm{F}$ düzeyinde bulunan her yanıt için 0 puan verilmiştir. Sekizinci ve dokuzuncu (8. ve 9.) sorular değerlendirilirken beşer soru içerdiklerinden A düzey yanıtlar için 15, B düzey yanıtlar için 12, C düzey yanıtlar için 9, D düzey yanıtlar için 6, E düzey yanıtlar için 3 ve F düzey yanıtlar için 0 puan verilmiştir.

Her ne kadar bu çalışmanın amacı HTA'nın öğrencilerin bazı istatistiksel kavramlarını öğrenmesi üzerindeki etkisini incelemek olsa da deney grubundaki öğrencilerin HTA ile verilen çalışma kağıtlarında ne tür cevaplar verdiği de önemlidir. Bu amaçla istatistiksel veri analizinin yanında öğrencilerin çalışma kă̆ıtlarında verdiği cevaplarda analiz edilmiştir. Deney grubunda öğrencilerin çalışma kâğıtları incelenerek her 
bir hata ile ilgili verilen yanıtlar üç farklı grup altında değerlendirilmiştir. Hatayı fark edemeyip hata yoktur yorumunda bulunan öğrenci yantları "hatayı bulamayan öğrenci", hatayı keşfetmesine rağmen düzeltme konusunda başarılı olamayan öğrencilerin yanıtları "hatayı bulan fakat düzeltemeyen öğrenci" ve hatayı bulup doğru yorumlayan öğrencilerin yanıtları “hatayı bulan ve düzelten öğrenci” olarak değerlendirilmiştir.

\section{Bulgular}

Ön Test Bulguları

Tablo 3'de grupların ön teste vermiş oldukları yanıtların ölçekteki düzeylere göre sayısal dağılımları verilmiştir.

Tablo 3. Grupların ön test yanitlarının frekansları

\begin{tabular}{llllllll}
\hline Grup & Tam & Kismen & $\begin{array}{l}\text { Doğrular } \\
\text { İçeren }\end{array}$ & $\begin{array}{l}\text { Yanlış 1 } \\
\text { (D) }\end{array}$ & $\begin{array}{l}\text { Yanlış 2 } \\
\text { (E) }\end{array}$ & $\begin{array}{l}\text { Yanıtsız } \\
\text { (F) }\end{array}$ & Toplam \\
& Doğru & $(\mathbf{A})$ & $(\mathbf{B})$ & $\mathbf{C})$ & & & \\
\hline Kontrol & 43 & 24 & 29 & 32 & 50 & 137 & 315 \\
Grubu & $\% 13.65)$ & $(\% 7.62)$ & $(\% 9.2)$ & $(\% 10.16)$ & $(\% 15.87)$ & $(\% 43.5)$ & $(\% 100)$ \\
\hline Deney & 67 & 33 & 25 & 24 & 33 & 133 & 315 \\
Grubu & $(\% 21.27)$ & $(\% 10.48$ & $(\% 7.94)$ & $(\% 7.62)$ & $(\% 10.47)$ & $(\% 42.22)$ & $(\% 100)$ \\
\hline Toplam & 110 & 57 & 54 & 56 & 83 & 270 & 630
\end{tabular}

Ön test sorularına verilmiş yanıtlara ait bulguların verildiği Tablo 3'e göre iki grup arasındaki en yakın durumun "yanıtsız (f)" düzeyinde olduğu tespit edilmiştir. Kontrol grubunda frekansı \% 43 olan değer deney grubunda \% 42 olarak saptanmıştır. Diğer yanıt düzeylerinde de iki grup arasında anlamlı fark yoktur.

Tablo 4. Grupların ön test puanlarına ilişkin $\mathrm{t}$ testi sonuçları

\begin{tabular}{lllllll}
\hline Grup & $\mathbf{N}$ & $\overline{\mathbf{X}}$ & $\mathbf{t}$ & $\mathbf{d f}$ & $\begin{array}{l}\mathbf{P} \\
\text { (2 yönlü) }\end{array}$ \\
\hline Deney Grubu & 20,57 & 35 &, 039 & 68 &, 969 \\
\hline Kontrol Grubu & 20,71 & 35 & & & \\
\hline
\end{tabular}


Tablo 4 Bağımsız örneklem t testi sonuçları incelendiğinde, gruplar arasında anlamlı bir fark olmadığ $(p>0,05)$, deney ve kontrol grubu ön test başarı düzeylerinin birbirine yakın ve dolayısıyla araştırma yapmak için bu grupların uygun olduğu söylenebilir.

\section{Son Test Bulgular}

Tablo 5'de grupların son teste vermiş oldukları yanıtların ölçekteki düzeylere göre sayısal dağılımları verilmiştir.

Tablo 5. Grupların son test yanitlarının frekansları

\begin{tabular}{|c|c|c|c|c|c|c|c|}
\hline Grup & $\begin{array}{l}\text { Tam } \\
\text { Doğru } \\
\text { (A) }\end{array}$ & $\begin{array}{l}\text { Kismen } \\
\text { Doğru } \\
\text { (B) }\end{array}$ & $\begin{array}{l}\text { Doğrular } \\
\text { İçeren } \\
\text { (C) }\end{array}$ & $\begin{array}{l}\text { Yanlış } 1 \\
\text { (D) }\end{array}$ & $\begin{array}{l}\text { Yanlış } 2 \\
\text { (E) }\end{array}$ & $\begin{array}{l}\text { Yanitsiz } \\
\text { (F) }\end{array}$ & Toplam \\
\hline Kontrol & 84 & 43 & 15 & 42 & 41 & 90 & 315 \\
\hline Grubu & $(\% 26.67)$ & (\%13.65) & $(\% 4.76)$ & (\%13.33) & $(\% 13.02)$ & $(\% 28.57)$ & $(\% 100)$ \\
\hline Deney & 187 & 36 & 26 & 30 & 5 & 31 & 315 \\
\hline Grubu & (\%59.37) & (\%11.43) & $(\% 8.25)$ & $(\% 9.52)$ & (\%1.59) & (\%9.84) & $(\% 100)$ \\
\hline
\end{tabular}

Tablo 5'de kontrol ve deney grupları son test yanıtları için verilen frekanslarda tam doğru (A) düzey yanıtların birbirine pek yakın olmadığı, kontrol grubu için \%27 olan değerin deney grubu için \%59 olduğu görülmektedir. Aynı şekilde soruları yanıtsız bırakan öğrenci sayılarında da ciddi bir fark olduğu söylenebilir. Kontrol grubunda yanıtların \%29’u yanıtsız (F) düzey kabul edilirken bu değer deney grubunda \%10 dur. Tablo 6'da bulunan bağımsız örneklem $t$ test sonuçları değerlendirildiğinde gruplar arasında anlamlı bir farkın olduğu $(p<0,05)$ ve bu farkın deney grubu lehine olduğu söylenebilir.

Tablo 6. Grupların son test puanlarına ilişkin $t$ testi sonuçları

\begin{tabular}{lccccc}
\hline Grup & N & $\overline{\mathbf{X}}$ & $\mathbf{t}$ & Df & P (2 yönlü) \\
\hline Deney Grubu & 35 & 75,3 &, 403 & 68 &, 000 \\
\hline Kontrol Grubu & 35 & 44 & & &
\end{tabular}

Grup ön test-son test sonuçları karşılaştırıldığında her iki gruba da yapılan müdahalenin etkili olduğu söylenebilir. Hangi müdahalenin daha etkili olduğunu anlamak için grupların son test sonuçları t-testiyle analiz edilmiştir. Bu bağlamda Tablo 6 incelendiğinde, grupların son test sonuçları arasında deney grubu lehine anlamlı bir fark olduğu görülmektedir $(\mathrm{t}=0,403$ ve $\mathrm{p}<0,05)$. Bu bulgu deney grubuna yapılan HTA yaklaşımının daha etkili olduğu şeklinde yorumlanabilir. 


\section{Uygulanan Çalışma Kă̆ıtlarına İlişkin Bulgular}

İstatistiki verilerin yanı sıra çalışma kağıtlarında öğrencilerin göstermiş oldukları performansta Tablo 7'de sunulmuştur. Bazı hataların düzeltilebilme frekansları yüksek iken bazı hataların öğrenciler tarafından tespit edilme frekanslarının düşük olduğu görülmektedir.

Tablo 7. Uygulanan çalışma kağıtlarında öğrenci yanıtlarının frekansları

\begin{tabular}{llll}
\hline Hata Numarası & $\begin{array}{l}\text { Hatayı bulup } \\
\text { düzelten öğrenci } \\
\text { sayısı }\end{array}$ & $\begin{array}{l}\text { Hatayı bulamayan } \\
\text { ögrenci sayıs }\end{array}$ & $\begin{array}{l}\text { Hatayı bulan fakat } \\
\text { düzeltemeyen } \\
\text { öğrenci sayısı }\end{array}$ \\
\hline 1.etkinlik 1. hata & 29 & 5 & 1 \\
\hline 1.etkinlik 2. hata & 30 & 4 & 1 \\
\hline 2.etkinlik 1. hata & 23 & 11 & 1 \\
\hline 2.etkinlik 2. hata & 3 & 25 & 7 \\
\hline 2.etkinlik 3. hata & 6 & 26 & 3 \\
\hline 3.etkinlik 1. hata & 28 & 4 & 3 \\
\hline 3.etkinlik 2. hata & 29 & 3 & 3 \\
\hline 4.etkinlik 1. hata & 17 & 15 & 3 \\
\hline 5.etkinlik 1. hata & 12 & 23 & 0 \\
\hline 5.etkinlik 2. hata & 20 & 15 & 0 \\
\hline 5.etkinlik 3. hata & 25 & 10 & 0 \\
\hline 6.etkinlik 1. hata & 6 & 29 & 2 \\
\hline 6.etkinlik 2. hata & 6 & 27 & 0 \\
\hline 7.etkinlik 1. hata & 22 & 13 & 0 \\
\hline 7.etkinlik 2. hata & 30 & 5 & 0 \\
\hline 8.etkinlik 1. hata & 10 & 25 & \\
\hline
\end{tabular}

Tablo 7'de ki verilere ilişkin 2. çalışma kağıdındaki ve 6. çalışma kağıdındaki hatayı bulan öğrenci sayılarında düşüklük görülmektedir. Yanıtlar göz önüne alındığında öğrencilerin önceki çalışma kağıdı ve hataların etkisinde kaldıkları görülmüş̧ür. Öğrenciler tarafından verilen yanıtları temsilen 1. çalışma kağıdında öğrencilerin vermiş oldukları yanıtlardan örnekler aşağıda sunulmuştur. Çalışma kağıdında çözümde iki hataya yer verilmiştir. Tablo 7'de görüldüğü gibi öğrencilerin büyük çoğunluğu istenen hedefe ulaşmış, hatayı bulup gerekli düzeltmeyi yapmışlardır. Ek 2'de sunulmuş olan çalışma kağıdına ilişkin öğrenci yorumları Resim 4, Resim 5, Resim 6 ve Resim 7'de sunulmuştur.

Birinci hata grafikte eksik nokta seçimidir. Çözümde 2013 ve 2015 yıllarında yirmişer ton olduğu söylenmeliyken sadece 2013 yılındaki 20 tondan bahsedilmiştir. 


\section{$b=$ yonlistir cónzi 2015 yilindada 20 ton olmustur}

Resim 4. Etkinlikteki birinci hataya ait öğrenci yorumu

Resim 4'te yanıtı verilen öğrencinin hatayı fark ettiği ve doğru sonuca ulaştığ1 “2015 yılında da" yorumundan görülmektedir.

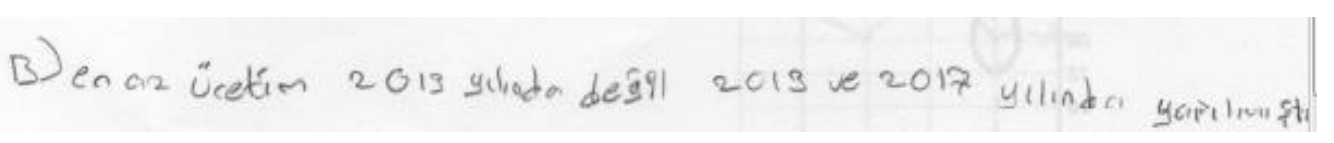

Resim 5. Hatayı fark eden fakat yanlış yorumlayan öğrenci yorumu

Resim 5'de yanıt veren öğrencinin hatayı fark ettiği fakat 2015 yılı yerine 2017 yılı yorumu yaptığı görülmektedir. Öğrencinin çalışma kâğıdı incelendiğinde grafik üzerinde bir işaretleme yapmadığı gözlenmiştir. Bu hata grafiği yanlış okumaktan kaynaklanıyor olabileceği gibi öğrencinin o an ki dikkatsizliğinden meydana gelmiş de olabilir.

Birinci çalışma kağıdında bulunan ikinci hatalı çözüm ise 5 yıllık toplam üretimi bulurken yapılmıştır. Yıllara göre üretim miktarlarının toplanması gerekirken yıllar toplanmıştır.

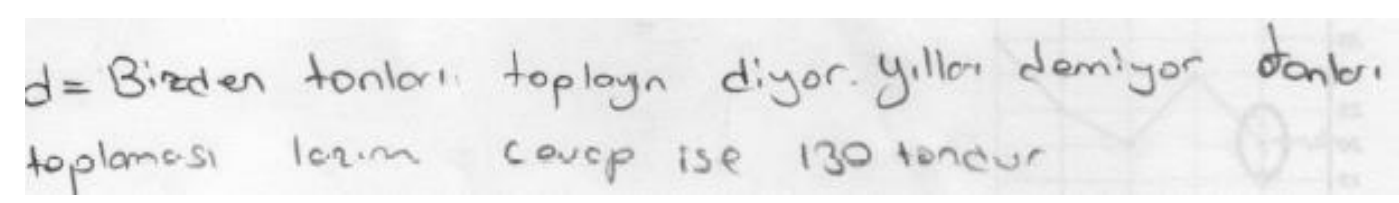

Resim 6. Etkinlikteki ikinci hataya ait öğrenci yorumu

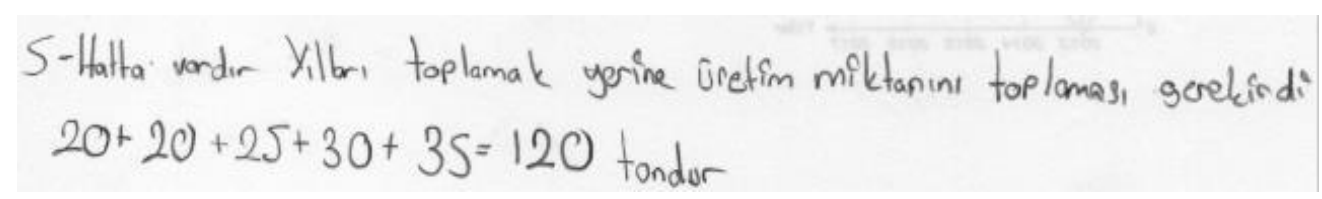

Resim 7. İkinci hatayı düzeltirken işlem hatası yapmış bir öğrencinin yanıtı

Resim 6'da verilen yanıta göre öğrencinin yapılan hatayı fark ettiği ve doğru yorumladığı görülmüştür. Resim 7'deki öğrencinin çözümdeki hatayı fark ettiği, doğru yorumladığı ve işleme doğru başladığı görülmektedir. Öğrencinin işlem yaparken toplamayı yanlış yaptığı için doğru sonuca ulaşamadığı görülmektedir.

\section{Tartışma, Sonuç ve Öneriler}

Hata temelli aktivitelerin 7. sınıf veri analizi alt öğrenme alanındaki bazı kavramlara ilişkin etkisinin araştırıldığı bu araştırmanın bulgularına göre, grupların ön test sonuçları 
arasındaki farkın istatistiksel olarak anlamlı olmadığı saptanmıştır. Bu sebeple grupların veri analizi alt öğrenme alanına ait çizgi grafiği, ortalama, medyan ve mod kavramlarındaki öğrenme düzeylerinin birbirinden farklı olmadığı söylenebilir. Grupların ön test-son test sonuçları incelendiğinde, her iki grubada yapılan müdahalenin etkili olduğu sonucuna ulaşılabilse de elde edilen sonuçlar HTA'nın klasik öğretim metoduna göre çizgi grafiği, mod, medyan ve aritmetik ortalama kavramlarını öğrenmede daha etkili olduğunu göstermektedir. Bu sonuçlar Siegler (2002) ve Stark vd. (2011) tarafından yapılan araştırmaların sonuçlarıyla paralellik göstermektedir. Kontrol grubu öğrencileriyle deney grubunun öğrencilerine ait sonuçların analizine bakıldığında hata temelli aktivitelerin etkili olduğu görülmüştür. Bu durum VanLehn (1999) çalışmasını doğrulamaktadır. Bu sonuç, HTA'nın zamanla öğrenme ortamlarında daha fazla kullanılabileceğiyle ilgili ipuçları vermektedir.

Deney grubu öğrencilerinin genel olarak aritmetik ortalama kavramına ilişkin öğrenmelerinin mod ve medyan kavramına ilişkin öğrenmelerine oranla daha iyi olduğu görülmüştür. Bu durumu ortaya çıkaran faktörün ne olabileceği düşünüldüğünde, öğrencilerin sınav notlarını hesaplamak için dahi sıklıkla aritmetik ortalama hesabı yapmak durumunda oldukları söylenebilir. Bu durum öğrencilerin aritmetik ortalama kavramındaki hazırbulunuşluk düzeylerinin daha iyi olmasını ve HTA'nın öğretim sürecinde daha etkili olmasını sağlamıştır. Buradan HTA'nın matematik kavramlarıyla ilgili hazırbulunuşluk düzeyleri iyi olan öğrencilerin öğrenmeleri üzerinde daha etkili olduğu söylenebilir. Nitekim Curry (2004), Stark vd. (2011) tarafından yapılan araştırmalarda benzer vurgular yaptıkları görülmüştür. Ayrıca Durkin ve Rittle-Johnson (2012), benzer şekilde konuyla ilgili hazırbulunuşluk düzeyleri düşük olan öğrencilerin doğru çözümlü örneklerden öğrenmesinin daha verimli olacağını aktarmışlardır. Buradan HTA'nın hazırbulunuşluk düzeyleri iyi olan öğrencilerin öğrenmesinde etkili bir strateji olduğu söylenebilir. Bu bağlamda Gentner, Loewenstein ve Thompson. (2003), hatalı çözüm örnekleri verilmeden önce çok sayıda doğru örnek sunmanın HTA'nın daha faydalı olacağını ifade etmektedir.

Deney grubundaki bazı öğrencilerin, çalışma kağıtları arası geçişte önceki hataların etkisinde kaldıkları gözlenmiştir. Örneğin; öğrencilerin önceki etkinlikte karşılaştığı “medyan için sıralama yapılmaması" hatasını sonraki etkinliklerde mod için de yapmaya çalıştıkları görülmüştür. Öğrencilerin hatalı çözüm örneklerinden öğrenme stratejisinde örnekleri birbiri ile karşılaştırarak hataları ele almaya çalışması başarısız denemeler ve sonuçlar 
oluşturmuştur. Öğrencilerin bu stratejiyi (örnekleri birbiriyle karşılaştırarak hataları bulmaya çalışması) etkili bir şekilde işe koşabilmeleri için iyi bir üst bilişsel beceriye sahip olmaları gerekmektedir. Nitekim bu durum Durkin ve Rittle-Johnson (2012), Gentner vd. (2003), Rittle-Johnson, Star ve Durkin (2010) çalışmalarında da görülmektedir.

Tablo 7 incelendiğinde bazı çalışma kağıtlarında hatayı bulamayan öğrenci sayısının yüksek olduğu görülmektedir. Çalışmanın nispeten başlarında uygulanan 2. çalışma kağıdında öğrencilerin zorlandığı düşünülse de, 5., 6. ve 8. çalışma kağıtlarında öğrencilerin hatayı bulmakta zorlanmadığı görülmüştür. Buna bağlı olarak özellikle bazı hataların bulunma oranının az olması dolayısıyla Enisoğlu'nun (2014) de çalışmasında değindiği gibi bu hataların yapılma eğiliminin daha fazla olduğu şeklinde yorumlanabilir. Bunun yanı sıra Siegler'nin (2002) de çalışmasında belirttiği gibi bu hatalara ilişkin daha fazla doğru çözümlü (sıradan) örneklerin çözülmesi hataların daha yüksek oranda bulunmasına katkı sağlayabilir.

İstatistik öğretimine ilişkin çalışmaların çoğunda (Ersoy, 2013; Özdemir, 2014; Şan, 2014; Ünlü, 2015; Yenilmez, 2016) başarıyı arttırmaya yönelik farklı yöntemlerin etkilerinden bahsedildiği görülmüştür. Farklı konuların öğretiminde HTA etkisinin incelendiği çalışmaların (Akkuşçi, 2019; Durkin, 2012; Gedik, 2014; Lynch \& Star, 2014; Rittle-Johnson vd., 2010) sonuçlarıyla bu çalışmada ulaşılan sonuçların paralel olduğu görülmüştür. Türkiye için yeni olan hata temelli aktivite stratejisinin de öğrencilerin bazı istatistik kavramlarındaki öğrenmelerini olumlu yönde etkilediği görülmüştür. Hata temelli aktivitelerin farklı matematik konularında ve farklı sınıf düzeylerinde yapılması önerilmektedir.

\section{Bilgilendirme}

Bu çalışma, ikinci yazarın, Adıyaman Üniversitesi, Fen Bilimleri Enstitüsünde yürütmüş olduğu "Hatalı Çözüm Metodunun 7. Sını Öğrencilerinin Bazı İstatistik Kavramlarındaki Başarısı Üzerindeki Etkisi" başlıkl yüksek lisans tezinden üretilmiştir.

Bu çalışmada kullanılan verilerin 2020 yılı öncesine ait olduğ u araştırmacılar tarafından onaylanmıştır. 


\section{Yazar Katkı Beyanı}

Ramazan GÜRBÜZ: Konu belirlenmesi, alanyazın taraması, kavramsallaştırma, metodoloji, veri toplama formunun hazırlanması ve geliştirilmesi, verinin işlenmesi, analizi, yorumlanması, denetim, inceleme-yazma ve düzenleme.

İshak YILDIRIM: Konu belirlenmesi, alanyazın taraması, kavramsallaştırma, metodoloji, veri toplama formunun hazırlanması ve geliştirilmesi, verilerin toplanması, işlenmesi, analizi, yorumlanması, incelenmesi ve yazma.

Muhammed Fatih DOĞAN: Araştırma konusunun belirlenmesi, kavramsallaştırma, veri toplama formunun hazırlanması ve geliştirilmesi, verinin yorumlanması, denetim, inceleme- yazma ve düzenleme.

\section{Kaynaklar}

Akkuşci, Y. E. (2019). Matematik öğretiminde hata temelli aktivite uygulamalarının sınıf içi kullanımının etkililiğinin incelenmesi. (Yayımlanmamış yüksek lisans tezi). Atatürk Üniversitesi, Eğitim Bilimleri Enstitüsü, Erzurum.

Balak, Z. (2021). Kareköklü ifadeler konusunun öğretiminde hatalı çözüm metodunun kullanılmasına ilişkin öğretmen görüşleri. (Yayımlanmamış yüksek lisans tezi). Adıyaman Üniversitesi, Lisansüstü Eğitim Enstitüsü, Adıyaman.

Ben-Zvi, D., Gravemeijer, K., \& Ainley, J. (2018). Design of statistics learning environments. In International handbook of research in statistics education (pp. 473-502). Springer, Cham.

Borasi, R. (1988). Towards a reconceptualization of the role of errors in education: the need for new metaphors. Paper presented at the Annual Meeting of the American Educational Research Association, New Orleans, LA. April, 1988.

Curry, L. A. (2004). The effects of self-explanations of correct and in correct solutions on algebra problem-solving performance. In Proceedings of the Annual Meeting of the Cognitive Science Society (Vol. 26, No. 26).

Durkin, K. (2012). The effectiveness of incorrect examples and comparison when learning about decimal magnitude (Doctoral dissertation, Vanderbilt University).

Durkin, K., \& Rittle-Johnson, B. (2012). The effectiveness of using incorrect examples to support learning about decimal magnitude. Learning and Instruction, 22(3), 206-214.

Durkin, K., Star, J. R., \& Rittle-Johnson, B. (2017). Using comparison of multiple strategies in the mathematics classroom: lessons learned and next steps. ZDM, 49(4), 585-597.

Enisoğlu, D. (2014). Seventh grade students' possible solution strategies, errors and misinterpretations regarding the concepts of mean, median and mode given in bar graph representations. Unpublished masters' thesis, Middle East Technical University, Graduate School of Social Sciences, Ankara.

Erenkuş, M. A., \& Savaşkan, D. E. (2018). Ortaokul ve imam hatip ortaokulu 7. sınıf matematik ders kitabı. Ankara: Koza.

Ersoy, E. (2013). Gerçekçi matematik eğitimi destekli öğretim yönteminin 7. sınıf olasılık ve istatistik kazanımlarının öğretiminde öğrenci başarısına etkisi. (Yayınlanmamış yüksek lisans tezi) Sakarya Üniversitesi, Eğitim Bilimleri Enstitüsü, Sakarya. 
Franklin, C., Kader, G., Mewborn, D., \& Moreno, J. P. R., Perry, M. \& Scheaffer, R. (2007). Guidelines for assessment and instruction in statistics education: A pre-k-12 curriculum framework.

Gaise, American Statistical Association. (2016). Guidelinesfor assessmentand instruction in statistics education.(gaise): collegereport 2016. alexandria, va: author. Retrieved from http://www.amstat.org/asa/files/pdfs/GAISE/GaiseCollege_Full.pdf

Garfield, J. \& Gal, I. (1999). Assessment and statistics education: Current challenges and directions. International Statistical Review, 67(1), 1-12.

Gedik, S. (2014). Matematik alan bilgisi geliştirme sürecine hata temelli aktivitelerin etkisi (Yayımlanmamış doktora tezi). Atatürk Üniversitesi, Erzurum.

Gentner, D., Loewenstein, J., \& Thompson, L. (2003). Learning and transfer: A general role for analogical encoding. Journal of Educational Psychology, 95(2), 393.

George, D. \& Mallery, M. (2010). SPSS for windows step by step: a simple guide and reference 17. Update (10 ed.). Boston: Pearson.

Große, C. S.,\& Renkl, A. (2007). Finding and fixing errors in worked examples: Can this foster learning outcomes? Learning and Instruction, 17(6), 612-634.

Gürbüz, R. (2007). The effects of computer aided instruction on students' conceptual development: A case of probability subject. Eurasion Journal of Educational Research, 28, 75-87.

Gürbüz, R.,\& Birgin, O. (2012). The effect of computer-assisted teaching on remedying misconceptions: The case of the subject "probability". Computers $\mathcal{E}$ Education, 58(3), 931-941.

Hall, S.,\& Vance, E. A. (2010). Improving self-efficacy in statistics: Role of self-explanation \& feedback. Journal of Statistics Education, 18(3).

Heinze, A. (2005). Mistake-handling activities in german mathematics classroom. in h.l. chick \& j. 1. vincent (eds.), Proceedings of the 29th Conference of the International Group for the Psychology of Mathematics Education (Vol. 3, 105- 112). Melbourne (Australien): Melbourne University.

Heinze,A. \& Reiss,K. (2007). Mistake-handling activities in the mathematics classroom: effects of an in-service teacher training on students' performance in geometry. Proceeding of the 31st Conference of the International Group for the Psychology of Mathematics Education (PME), 3, 9-16.

Karaatlı, M., Helvacioğlu, Ö. C., Ömürbek, N., \& Tokgöz, G. (2012). Yapay sinir ağları yöntemi ile otomobil satış tahmini. Uluslararası Yönetim İktisat ve İşletme Dergisi, 8(17), 87-100.

Konyalığlu, A. C., Özkaya, M, Gedik, S. D. (2019). Matematik öğretiminde hata temelli aktiviteler (Genişletilmiş Baskı). Erzurum: Ertual Akademi Yayıncılık.

Koparan, T., Güven, B. \& Karataş, İ. (2012). Lise öğrencilerinin veri analizinde bağlam bilgileri ile matematiksek/istatistiksel bilgilerini kullanım şekilleri. Journal of Computer and Education Research, 2 (4), 1-22.

Lynch, K., \& Star, J. R. (2014). Teachers' views about multiple strategies in middle and high school mathematics. Mathematical Thinking and Learning, 16(2), 85-108.

Memnun, D. S. (2008). Olasılık kavramlarının öğrenilmesinde karşılaşılan zorluklar, bu kavramların öğrenilememe nedenleri ve çözüm önerileri. İnönü Üniversitesi Ĕ̆itim Fakültesi Dergisi, 9(15), 89-101.

Milli Eğitim Bakanlığ1 Temel Eğitim Genel Müdürlüğü. (2018). Matematik dersi öğretim programi. Ankara: MEB. 
Örnek, T. \& Soylu, Y. (2021). Problem kurma becerisini geliştirmek için tasarlanan problem kurma öğrenme modeli'nin değerlendirilmesi. Journal of Computer and Education Research, 9(18), 929-960. DOI: 10.18009/jcer.949572

Özdemir, S. (2014). İstatistik dersinde işbirlikli öğrenmenin öğrencilerin akademik başarılarına, tutumlarına etkisi ve istatistiksel düşünme seviyelerinin incelenmesi. (Yayınlanmamış Yüksek Lisans Tezi), Çukurova Üniversitesi, Adana.

Özkaya, M. (2015). Hata temelli aktivitelerin matematik öğretmenlerinin mesleki gelişimlerine etkisinin incelenmesi. (Yayınlanmamış Doktora tezi). Atatürk Üniversitesi Eğitim Bilimleri Enstitüsü, Erzurum.

Özmen, Z. M. (2015). Examination of the statistical literacy levels of students from different undergraduate programs (Unpublished doctoral dissertation). Karadeniz Technical University, Graduate School of Nature Sciences, Trabzon, Turkey.

Rittle-Johnson, B., Star, J., \& Durkin, K. (2010). Developing procedural£ flexibility: When should multiple solution methods be introduced. In Annual meeting of the American Educational Research Association, Denver, CO.

Sevimli, N. E. (2010). Matematik öğretmen adaylarının istatistik dersi konularındaki kavram yanılgıları; istatistik dersine yönelik öz yeterlilik inançları ve tutumların incelenmesi. (Yayınlanmamış Yüksek Lisans Tezi). Marmara Üniversitesi Eğitim Bilimleri Enstitüsü, İstanbul.

Sezer, N. (2013). İstatistiğin temel kavramlarının probleme dayalı öğrenme yaklaşımıyla öğretimi. (Yayımlanmış yüksek lisans tezi). Uludağ Üniversitesi, Bursa.

Siegler, R. S. (2002). Microgenetic studies of self-explanation. Microdevelopment: Transition processes in development and learning, 31-58.

Stark, R., Kopp, V., \& Fischer, M. R. (2011). Case-based learning with worked examples in complex domains: Two experimental studies in undergraduate medical education. Learning and instruction, 21(1), 22-33.

Şan, İ. (2014). 7. Sinı matematik dersi olasılık ve istatistik öğrenme alanının öğretiminde "sınav yoluyla öğrenme yöntemi" nin öğrencilerin akademik başarı, tutum ve sınav kaygısına etkisi. (Yayınlanmamış Doktora Tezi), İnönü Üniversitesi Eğitim Bilimleri Enstitüsü, Malatya.

Türkdoğan, A. \& Baki, A. (2021). The relation between mistakes and feedbacks encountered in mathematics course in the 7th grade. Journal of Computer and Education Research, 9 (17), 480-496. DOI: $10.18009 /$ jcer. 856700

Ünlü, V. (2015). 7. sını matematik dersi "olasılık ve istatistik" öğrenme alanında yazma etkinliklerinin öğrencilerin başarısı, tutum ve üst bilişlerine etkisi (Yayımlanmamış yüksek lisans tezi). Gazi Üniversitesi, Ankara.

Van Den Broek, P.,\& Kendeou, P. (2008). Cognitive processes in comprehension of science texts: The role of co-activation in confronting misconceptions. Applied Cognitive Psychology: the Official Journal of the Society for Applied Research in Memory and Cognition, 22(3), 335-351.

VanLehn, K. (1999). Rule-learning events in the acquisition of a complex skill: An evaluation of CASCADE. The Journal of the Learning Sciences, 8(1), 71-125.

Yenilmez, İ. (2016). İstatistiksel kavramların teknoloji ile öğretiminin matematik didaktiği perspektifinden incelenmesi. (Yayımlanmamış yüksek lisans tezi). Marmara Üniversitesi, Eğitim Bilimleri Enstitüsü. İstanbul. 
1) “Burçak, annesinin aldığı altılı yumurta kolisinin etiketinde bir yumurtanın ortalama 60 gram olduğunu görür ve bunun doğruluğunu merak eder. Yumurtaları mutfak terazisi ile tartar ve ağırlıklarını; 58 g, 68 g, 67 g, 60 g, 45 g ve 62 g olduğunu görür." Bu değerlere göre verilen ortalama doğru mudur? Açıklayınız.

2) Bir öğrenci matematik sınavından 80 ve 82 notlarını almıştır. Bu öğrencinin üçüncü matematik sınavından aldığı not ile birlikte karnesine tam 85 düşmüştür. Bu öğrenci üçüncü matematik sınavindan kaç almıştır?

3) Elif matematik sınavından 4, 2 ve 3 notlarını almıştır.

a) Elif'in aldığı bu notlarla karnesine matematik notu kaç düşer?

b) Eğer Elif bu notları değil de, girdiği üç sınavdan da 3 almış olsaydı karnesine düşecek olan notu değişir miydi?

4)Bir doktor bir günde 10 hasta muayene ediyor. Bu hastaları muayene etme süresi dakika olarak aşağıdaki gibi verilmiştir.

$15 \mathrm{dk}, 25 \mathrm{dk}, 40 \mathrm{dk}, 25 \mathrm{dk}, 13 \mathrm{dk}, 30 \mathrm{dk}, 17 \mathrm{dk}, 23 \mathrm{dk}, 25 \mathrm{dk}, 3 \mathrm{dk}$

Bu doktorun hasta muayene etme süresinin tepe değeri kaçtır?

5) Bir konserde sanatçının isteği üzerine, konsere gelen kişiler konser alanında boy sırasına göre dizilmek zorundadırlar. Konsere gelen ilk 11 kişinin boy uzunlukları $172 \mathrm{~cm}, 152 \mathrm{~cm}, 182 \mathrm{~cm}, 149 \mathrm{~cm}$, $148 \mathrm{~cm}, 150 \mathrm{~cm}, 165 \mathrm{~cm}, 162 \mathrm{~cm}, 155 \mathrm{~cm}, 146 \mathrm{~cm}$ ve $178 \mathrm{~cm}$ 'dir. Buna göre bu kişilerin medyanı kaçtır? 6) Bir ekmek fırını önünden ramazan pidesi almaya giden kişilerin yaşları aşağıda verilmiştir.

$$
72,10,45,11,37,12,54,14,42,18,20,17
$$

Bu fırına gelen müşterilerin kendi aralarında alışmış oldukları bir kural vardır. Bu kurala göre; fırına gelen kişiler yaşlarına göre büyükten küçüğe göre sıraya girmek zorundalardır. Müşteriler sıraya girmiş ve sadece sıranın ortasına yetecek kadar pide kalmıştır. Sizce kaç yaşındaki kişi de pide biter? Bu matematikte öğrenmiş olduğunu hangi matematiksel bilgi ile açıklanabilir?

7) Gamze bir hafta boyunca her gün kitap okumuş ve okuduğu sayfa sayılarını aşağıdaki tabloda not etmiştir.

\begin{tabular}{|l|l|}
\hline Pazartesi & 24 \\
\hline Salı & 21 \\
\hline Çarşamba & 26 \\
\hline Perşembe & 24 \\
\hline Cuma & 27 \\
\hline Cumartesi & 32 \\
\hline Pazar & 28 \\
\hline
\end{tabular}

a)Bu tabloya göre Gamze'nin bir hafta boyunca okuduğu sayfa sayısının aritmetik ortalaması kaçtır?

b)Gamze'nin bir hafta boyunca okuduğu sayfa sayılarının medyanı kaçtır? c)Gamze Salı günü hiç kitap okumasaydı medyan değişir miydi? Aritmetik ortalama değişir miydi? 
8) Așağıdaki çizgi grafiḡinde bir çiftçinin 5 yılda ürettiḡi patates miktarları gösterilmiștir. Grafiḡe göre așağıdaki soruları cevaplayınız.

Grafik: Pafates Üretim Miktarları

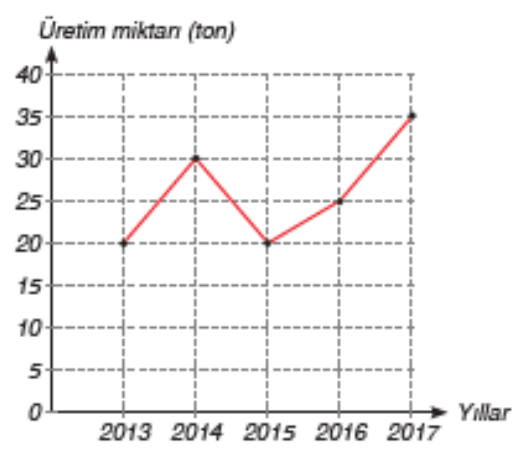

a. En fazla üretim hangi yılda ve kaç ton olmuştur?

b. En az üretim hangi yılda ve kaç ton olmuştur?

c. Üretim miktarlarının aynı olduḡu yıllar hangileridir?

c. 2017 ile 2013 yıllarındaki üretim farkı kaç tondur?

d. 5 yıllık üretim kaç tondur?

9) Așaḡıdaki çizgi grafiğinde bir sınıftaki ögrencilerin maternatik dersinde aldığı notların daḡılımı verilmiștir. Buna göre aşaḡıdaki soruları cevaplayınız.

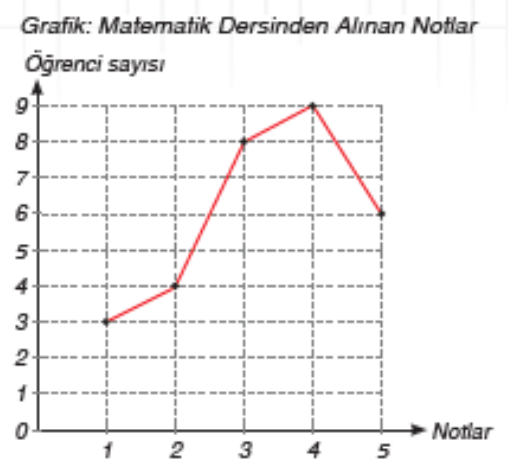

a. En yừksek notu alan ōğrenci sayısı kaçtır?

b. En düșük notu alan öğrenci sayısı kaçtır?

c. Sınıf mevcudu kaçtır?

c. 1'den fazla not alan öğrenciler başarılı sayıldıḡına göre bașarılı öḡrenciler, bașarısız ōḡrencilerin kaç katıdır?

d. Bu sınıfın bașarı oranı yüzde kaçtır?

\section{Ek-2 Örnek çalışma kâğıdı}

Bir çiftçisiniz ve patates ihraç ediyorsunuz. Son 5 yıla ait patates üretiminiz grafiktedir.

Muhasebecinizi çağırıp aşağıdaki sorulara cevap vermesini istediniz.

\section{Grafik: Patates Üretim Miktarları}

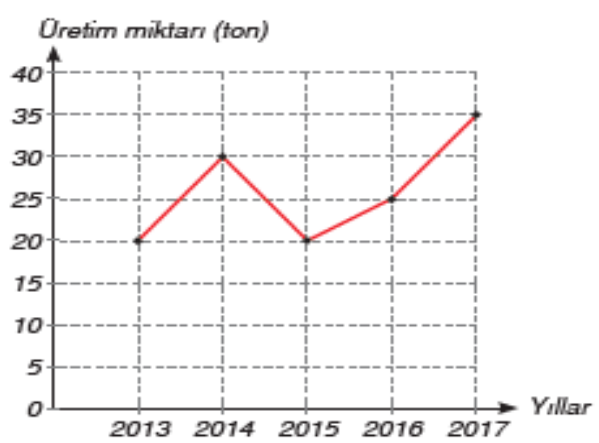

a) En fazla üretim hangi yılda ve kaç ton olmuştur?

b) En az üretim hangi yılda ve kaç ton olmuştur?

c) Üretim miktarlarının aynı olduğu yıllar hangileridir?

d) 2017 ile 2013 yıllarındaki üretim farkı kaç tondur?

e) 5 yıllık üretim kaç tondur? 
Grafik: Patates Üretim Miktarları
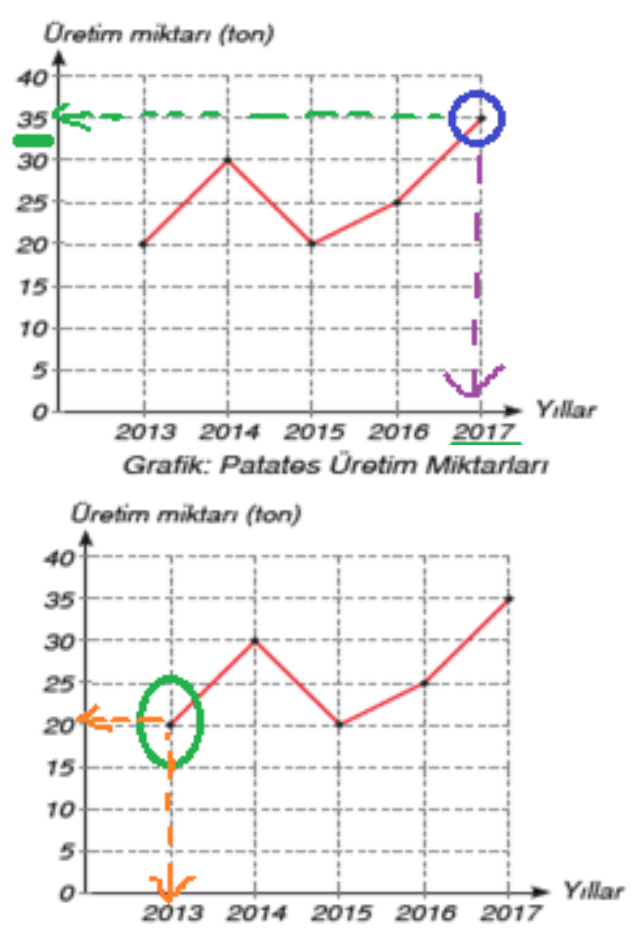

Grafik: Patates Üretim Miktarları
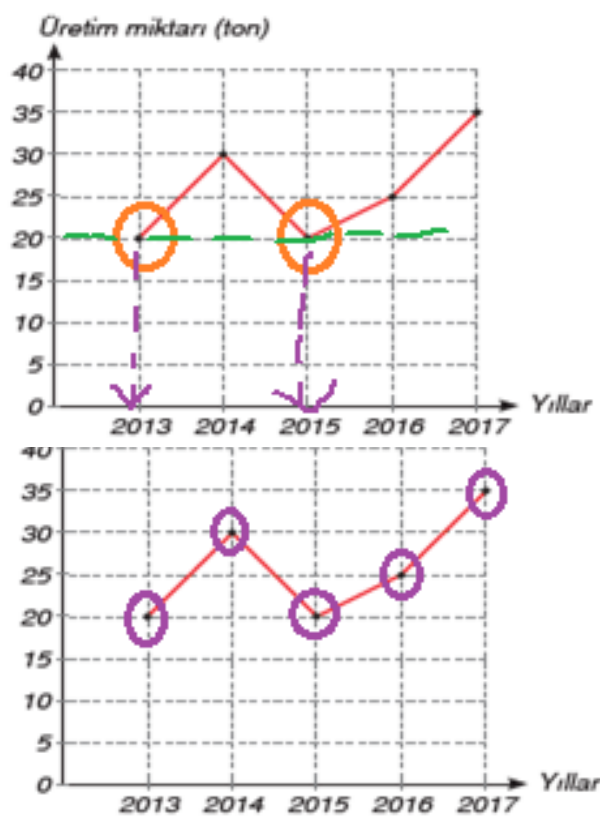

5 yıllık toplam üretim 10075 tondur. a) Grafiğe bakıldığı zaman dikey eksenin üretim miktarı olduğu görülmüştür. Dikeydeki en yüksek nokta bize üretim miktarının en yüksek kaç ton olduğunu ve buna karşılık gelen yatay eksendeki yıla bakınca da hangi yıl olduğunu söyleyecektir.

En fazla üretim 2017 yılında 35 ton olmuştur.

b) En az üretim için grafikte dikeydeki en düşük noktayı bulmalıyız. Dikeydeki en düşük nokta 20 tonu göstermektedir.

En az üretim 2013 yılında 20 ton olmuştur.

c) Üretim miktarlarının aynı olması için yatay olarak aynı seviyede noktaların olması gerekiyor, grafiğe baktığımız zaman 20 tonu gösteren iki noktanın olduğunu görüyoruz;

2013 ve 2015 yıllarında 20 şer ton ile üretim miktarları aynidir.

d) 5 yıllık üretimi bulmak için grafikteki bütün noktalara karşılık gelen değerleri toplamalıyız;

$2013+2014+2015+2016+2017=10075$ ton

2013 yilında 20 ton,

2014 yilında 30 ton,

2015 yilında 20 ton,

2016 yilında 25 ton,

2017 yılında 35 ton üretim yapılmıştır.

$2013+2014+2015+2016+2017=10075$

Sıra Sizde: Yukarıda muhasebecinizin sorulara verdiği cevapları inceleyiniz, muhasebeciniz sonuçlara ulaşmaya çalışırken hata yapmış mıdır? Eğer hata yaptığını düşünüyorsanız hatalarını ve doğru yanıtları yazınız? Bu hataları nasıl buldunuz? 